\title{
FRUCTIFEROUS EXILE: MARTINEZ ESTRADA AND THE ENCOUNTER WITH MARTI
}

James Maharg

Literary friendships have always offered a certain fascination for the critic, and rightly so. In one fell swoop, as it were, the chronicles of such friendships have promised to yield fruitful insights into the lives, literary and trivial, of two creative artists, with all their attendant hopes, failures and triumphs. Additionally, these relationships have frequently provided rare instances of intimacy, even painful sincerity, that their respective works have suggested in only the most oblique fashion. Thus Boswell not only sheds considerable light on the work of Johnson and vice versa, but we are also there by witnesses to a much more complete image of the personalities of both. Not unexpectedly, literary friendships are rarely the mirror image of their components; almost inevitably the relationship is one of dominance and dependence, an inequality freely embraced and entered into on the at least implicit recognition of the acendancy of one of the parties upon the other. Thus despite Boswell's considerable claim to literary merit, his devotion to Johnson served the latter's reputation more than his own.

Examples of literary friendships in this sense (as opposed to common friendships among fellow artists) do not abound in Latin American literature. Certainly it has produced artists of universal achievement who have had a profound effect on generations of "writers who have oriented their work in the powerful luminosity of the former's legacy. But this is not the same case as those rare individuals who have accomplished a truly transcendental meeting of minds and hearts that transformed their personalities as much as their work. XXth century Argentine literature, however, has offered the critic two examples of this relationship, the first rather widely recognized, and the second only recently having begun to receive attention. ${ }^{1}$ I refer to the friendship between Martínez Estrada and Horacio Quiroga, and the relationship between the essayist and Jose Martí. By all accounts, not least Martínez Estrada's own testimony in El hermano Quiroga, the first was of primary importance to the whole direction of his literary career and is commonly held to be the motivating factor for his virtual abandonment of a highly successful poetic career at the beginning of the 1930 ' $^{2}$. The enormous impact of Quiroga on Martínez Estrada, however, came as a culminating influence upon the essayist, the finding of a kindred spirit who confirmed and strengthened certain postures, ideas and suspicions that had been formed much earlier. ${ }^{3}$ In another sense, too, practically all of Martínez Estrada's friendships were literary. It was his fate (disposition?) to enjoy very few ordinary friendships throughout his life, whereas the figures of his literary biographies produced in him a deep sense of revelation and excitement. Hence Balzac, Nietzsche, Montaigne, Hudson and Kafka came to substitute, and to a considerable degree 
compensate for, the lack of understanding he encountered around him. As a result, Martínez Estrada was accurately left open to the criticism that his approach to these writers suffered from a desire to interpret them from the perspective of his own problemática, thus producing studies that were basically in his own image and likeness.

His work on Jose Martí, on the other hand, was significantly different from any of his other literary biographies. What it shared with them was a great sense of coincidence with many of the travails of his own life; that the life of the artist was fundamentally a priesthood of contracted moral imperatives catalyzed by an elemental vision of the human condition that could admit of no possible prevarication or compromise in it's realization; and that the artist was inherently the self-appointed interpreter of the infra-history of a nation, of humanity itself. Hence the following comment on Nietzsche could well be Martínez Estrada's own epitaph:

No mentirse a sí mismo, no tener miedo, no detenerse a la mitad del camino sino llegar hasta las últimas consecuencias, o hasta las últimas posibilidades de llegar; ser un vikingo, ésa es su misión. ${ }^{4}$

But Martí conveyed more to the essayist than an admirable moral fortitude and intellectual honesty. Fundamentally, the Cuban offered him a vision of America that transcended anything that he-had known previously, and thereby caused him to consider his work on Martí as virtually the crowning achievement of his life. ${ }^{5}$ Standing then more than thirty years apart, the influence of Quiroga and Martí came at two significant, even critical points in his life, the one to initiate, in the essayist's own words, his "campaign in the desert", and the other to confirm that it had all been worthwhile.

\section{Martínez Estrada in 1959}

In retrospect the whole of the essayist's career appears to lead up to the encounter with Martí a few years before his death. For decades he had been in a state of war, declared over and over, with what he viewed as a literary tradition that had prostituted itself to capitalist interests in the nineteen century (exception made of Sarmiento and Hernández) and that had been willingly perpetuated into the twentieth. It was a conflict between himself and the "merchants of knowledge", "the pharisees and scribes of culture" and the "falsifiers of truth", the first battle of which, if not the first shot, was Radiografia de la pampa (1933). Throughout the great majority of his twenty-seven essays he sought to expose his conviction that Argentine culture was a pseudo-culture stagnating in the quagmire of an organic sickness that was well-nigh incurable. Writing in a highly intuitive manner and using a vocabulary that frequently relied upon the use of mystiques, Martínez Estrada stood apart from literary movements and epochal styles, and thereby constituted a disturbing ambiguity for XXth century Argentine literary criticism. The basic irony of his career was that his discursive manner represented a barrier to the communication that he strived to achieve with others, and almost without exception he interpreted the repudiation of his message as bad faith, or even betrayal. This in turn only served to strengthen his resistance, and inevitably, to cause him to withdraw increasingly into himself, under the aegis of a temperament that, aptly summarized by César Fernández Moreno, "suele encontrar mediocre lo bueno, malo lo mediocres, y atroz lo 
malo. La natural polaridad de su mente lo lleva a desmensuradas oposiciones frente a los conceptos corrientemente aceptados." Yet in personal terms Martinez Estrada was to suffer considerably for his adopted role of Biblical prophet calling his country to face up to its cultural inauthenticity, and if vacilation of resolve never presented itself, he had motive to pause occasionally at the extent of the criticism he had brought upon himself:

Aparecía yo muchas veces como un salvaje, un mal educado y hasta un nihilista, obligándoseme a presentar mis excusas a cada instante y a quedar hundido en dudas inhibitorias acerca de la validez de mis opiniones. ${ }^{7}$

Such moments were quite rare. The increasing withdrawal we have referred to more frequently engendered statements that, in self-justificatory tone, assailed the nation for its ungrateful treatment of "an impartial observer of the facts", as the author described himself. In 1959 he opted for self-imposed exile in Mexico and Cuba, and did not return to Argentina until 1963. In a speech given in Mexico in 1960, remarkable for its pathos and revelation of the extent of a growing persecution complex, Martinez Estrada declared:

Adiós, opulenta nación de ganados y mieses, que honras con magnificencia y estrépito de clarines a tus héroes y mártires muercos en el destierro. Alegra tu corazón con vino de tus bodegas y pan de tus graneros; solázate con la música de las trompetas y los atanales y no escuches la voz trémola de los profetas en el destierro. Sé feliz y prospera...

Pues ocurrió primero que por haber revelado la índole hereditaria y crónica de los males que a mi juicio aquejan a mi país y denunciando luego a quienes creí que debiéramos culpar de ellos, vine a encontrarme como extranjero en mi patria, perdidos algunos amigos ilustres y ganados, otros apenas alfabetos; cerradas las puertas de diarios y revistas y señalado por índice de los amos de la patria. Arrojado, digo, a las ergástulas del pueblo. . Aquí quisiera morir, y la gloria que pido es el olvido y la paz. ${ }^{8}$

There is evidence to suggest that there was not a little exaggeration in all of this ${ }^{9}$, but there can be little doubt that the essayist was sufficiently convinced of the futility of further proclaiming his mission in Argentina. In spite of his invitations to México by the Fondo de Cultura Económica and to Cuba by Casa de las Américas, at the outset they promised little aleviation of a conviction of defeat augmented by acute despondency, that had been developing in Martínez Estrada over the years. The reception given to his historico-sociological essays (e.g. Radiografía de la pampa. La cabeza de Goliat, Muerte y transfiguración de Martin Fierro) his literary essays (e.g. Heraldos de la verdad, Realidad y fantasia en Balzac) and to his polemical work (e.g. Cuadrante del pampero, ¿Qué es esto? , Las 40) enveloped him in continual controversy from the beginning, not unusual in view of his stated aim of re-evaluating the whole direction of Argentine literature and history. In 1959, however, and at the age of sixty-four, the accumulative effect, as he saw it, of incomprehension and bad faith, together with that of a painful skin disease that had kept him bedridden for several years, represented without doubt the high point of his despair. 


\section{The progressive Americanization}

Despondency was not the only factor that led Martinez Estrada to abandon Argentina, despite its crucial significance. The whole orientation of his work over the twenty-six years since the appearance of Radiografia de la pampa on examination reveals an increasing Latin American awareness. Moreover, he had travelled to Cuba twice before 1959, and also to Chile, Bolivia, Uruguay and Brazil, and his most obviously Latin American work, Diferencias y semejanzas entre los paises de la América Latina (1962) also the most voluminous to that point - was published before his essays on the theme of Martí. ${ }^{10}$ Radiografía de la pampa of course was not a uniquely Argentine treatise, and the author frequently gave his conclusions a wider context. Similarly, in his work on Sarmiento (Sarmiento, Los invariantes históricos en el Facundo) the continental awareness of the author is quite explicit:

\footnotetext{
Facundo es una autobiografía, y una sociología, una obra literaria y un fragmento de historia, una acusación de defensa de los pobres y ausentes y un capítulo de la antropología americana. También era una tentativa para la investigación de la historia más que una simple galería de personajes, y pintura de ambiente. .. 11
}

This one example will suffice for the many others to be found throughout his essays, but here too the critic is witness to another parallel process that accompanied the growth in his Latin American awareness: that of an increasing radicalization of thought. The matter is important because it establishes further a predisposition on the part of the essayist for having sought exile in 1959. Additionally, it helps to explain the appearance of the author's rather crudely propagandistic work, El verdadero cuento del Tio Sam (1963), which otherwise might be interpreted as an idiosyncratic quirk of an encroaching senility. It also explains to a large degree Martínez Estrada's energetic defence of the radicalization of Cuban politics against a declaration by Argentine writers that included Borges, Mallea and Bioy Casares:

En fin esa declaración con la que desengañan a los aficionados a la literatura de imaginación que creyeron pertenecían ustedes a la intelectualidad argentina - a la alta, por supuesto -, deja la convicción de que ignoran ustedes cómo se vive, se trabaja, se estudia y se construye sobre las ruinas de un régimen ominoso un nuevo mundo de paz, de confraternidad en Cuba. Yo estoy aquí y lo veo. ${ }^{12}$

Moreover, the frankly political nature of these essays is strongly reminiscent of his previous polemical essays that we have referred to, and to that extent the tendentious nature of much of this period is not "out of character", as was suggested in Argentina at the time. No critic has seriously suggested that El verdadero cuento del Tio Sam and En Cuba y al servicio de la revolución cubana are among the essayist's more artistic achievements, but they are at least consonant in substance and tone with earlier Argentine essays that were clearly not literary in intention or effect. In short, Martínez Estrada made his encounter with the work of Marti at a time of deep disillusionment with regard to the efficacy of his work in Argentina, but equally, the progressive radicalization and americanization of his work created the frame of mind upon which the Cuban was to have such a profound effect. 


\section{Encounter with Martí}

Martínez Estrada had approached the work of Martí before his invitation to Cuba in 1961, principally an article comparing him with Sarmiento that he had published in 1941. ${ }^{13}$ In two visits to the island in 1948 and 1949 , he was made a Caballero de la Orden Nacional de Mérito Carlos Manuel de Céspedes and academician of the Academia de Historia respectively and to that extent he could not have failed to observe the primancy given to the Apóstol in Cuban history and culture. As we have shown, however, the morale of the essayist at the beginning of the 1960's was quite different from previous years, and what he now found was an example of extreme courage and abnegation in a series of adverse situations. Most of all, he was deeply impressed by the singlemindedness with which Martí pursued his ideals, primarily that of the cultural and political emancipation of Latin America. The strongly humanist appeal of such a position stood in clear opposition to the values of a mechanized culture ("la cultura kitsch") and against which Martínez Estrada had directed continual tirades:

El material específico de la cultura se confunde con el conjunto circulante de los bienes del confort doméstico y espiritual que la sociedad prepara y distribuye economizando esfuerzos y gastos superfluos al consumidor. Simultaneamente, pues, y por un juego de balancines, a medida que se eleva el firdice del valor puro de la técnica de laboratorio y de su sección subordinada, la ciencia industrializada, desciende el del saber lúcido o sapencial. $^{14}$

It was precisely this "saber sapencial", a highly intuitive function that cut through all logic and systems to arrive at the heart of the matter, that which Martinez Estrada had appreciated in Sarmiento, then in Hernández, and which he found to an unsuspected degree in Martí. The possession of such a faculty was the closest the author ever came to a definition of genius, or rather its fundamental prerequisite; moreover, it was as much an instrument for the sure investigation of a culture's past as of its present. Commenting on Martí's religious sense in Martí revolucionario, he wrote:

La religión, para Martí como para los espíritus de su envergadura, no es cuestión de parroquia ni de pastoral: abarca la esfera de los grandes sentimientos impersonales y ancestrales, y la esfera de las altas ideas de los teólogos presocráticos y de los místicos medievales, no en términos gramaticales y filosóficos con que ellas se plantaron sino con la misma profunda convicción de lo infinito, lo incognoscible, y lo inefable.

El cristianismo de Martí es humanitarismo más que religión especulativa . . lo lo esencial en el cristianismo de Martí no es lo que Cristo cataliza en dirección de un credo y dogma religiosos, sino lo que era anterior a él y que subsiste fuera del ámbito religioso y místico. . 15

Thus what Martínez Estrada perceived in Marí was the configuration of a powerfully innate intelligence and a spiritual concept of historical man that far transcended the faculties of ordinary mortals. When this was augmented by a highly idealistic vision of the destiny of the sub-continent, the effect was quite irresistible for the essayist. Further, if the Cuban possessed a sense of duty to humanity itself (an ideal that pervades much of Martínez Estrada's work), his particular commitment to hispanoamerican culture and above all his understanding of its infra-history, was equally overpowering for the Argentinian's sensibility. Martí, like Sarmiento, had realized that the principal human 
constants running throughout Latin American history were not its ideas but rather its "reflejos incondicionados de conducta social", its "gestos", and "inflexiones prosódicas". Moreover, Marti's poetic penetration of the primordial secrets of Latin American nature were seen as a highly developed sense of lo telúrico:

Todo lo que la naturaleza produce, para Martí es venerable, pero en su misma forma de acción y reacción instantáneas, no de culto o rito pagano. Las plantas más que los animales como seres absolutamente elementales, plegados en sí mismos, identificados como seres intrauterinos de la madre tierra, todavía en simbiosis con ella, pacientes, silenciosos y benéficos. ${ }^{16}$

It is obvious here that we are beyond the confines of the rational, and even further removed from the restraints of a scientific and technological view of life for which Martínez Estrada reserved his most bitter diatribes. Hence as a concomitant to the essayist's tendency to see the authors he studied from the standpoint of his own ideological priorities, those, like Martí who shared his opposition to the same or similar concepts, received quite sympathetic treatment.

The greatest point of attraction for Martínez Estrada, however, was Martís resolute pursuit of his ideals, illuminated by a self-abrogated sense of mission. In Martí: el héroe y su accion revolucionaria (1966), the essayist discussed tho theme at lenght, as that of Martí's virtual sacrifice of his family to that pursuit, in Familia de Marti (1962). Again, much of that discussion frequently appeared as a statement of the Argentinian's own life experience:

\begin{abstract}
¿Qué motivos pueden determinar a alguien a asumir la representación de una comunidad, inclusive el pueblo de un país, para exigir en su nombre un cambio de la estructura social, una revolución? El mandato no existe, la representación es cuestionable, acaso la mayoría de los individuos ignoran la existencia y la representación que ese alguien invoca. Sólo un gran ideal, una fe fanática puede decirlo. . . No vivimos razonando nuestros actos sino dentro de una línea de conducta y de un modo de ser y de actuar que rige cada uno de nuestros actos. Tampoco vivimos por entero para nosotros, sino, en gran parte, para los demás, no siempre para nuestro bien sino para la felicidad de los otros. Así piensan los redentores y los revolucionarios. ${ }^{17}$
\end{abstract}

With this we have arrived at the culminating effect of the influence of Martí upon Martinez Estrada. At precisely the moment of greatest despair and disillusionment with regard to the efficacy of his mission in Argentina, the essayist not only discovered a model of perseverance right to the final sacrifice, but above all that many of the ideals that he had set himself had been achieved by Martí. No only did Martínez Estrada find, to paraphrase Thoreau's celebrated metaphor, that in so much they had heard the same beat of the same distant drum, but also that he became convinced that Martí had reached its source. The corollary of this, of course, is that Martinez Estrada finally realized that in the context of his own life's work, he was not destined to become either a redeemer or a revolutionary, but far from succumbing to disappointment, he felt himself renewed and reinvigorated at having touched the mantle of one who had become both.

Thus we return to our earlier comments about literary relationships. His deeply humanistic interpretation of the life and work of Martí has served to reinforce several 
points of the Cuban's reputation, as we have suggested is the way with the innate inequality of most literary friendships. But the essayist's work on Martí represents an exception, at least partial, in that his two volumes dedicated to the Cuban figure among the best he produced on any theme. Separated in time from the contemporary frame characteristic of such friendships, Martínez Estrada achieved an admirable degree of understanding of Martí, and in the process, a far-reaching justification of his literary and social mission expressed thirty years previously, and equally, a measure of compenetración that meant the difference between the darkness of failure and the light of self-realization.

Department of Spanish, Italian and Portuguese

University of Illinois at Chicago Circle

Chicago, USA

\section{NOTES}

${ }^{1}$ See the perceptive article by Alexander Coleman, "Martí y Martínez Estrada: historia de una simbiosis espiritual," Revista Iberoamericana, XLI, nos. 92-93 (July-December, 1975), 629-641.

2 "Él me inició en la lectura de obras desagradables, que había considerado yo de menor cuantía y fuera de los cánones del gran estilo, y extinguió en mi la lámpara mortecina de la poesía que había iluminado los lóbregos senderos de mi juventud." El hermano Quiroga (Montevideo: Arca, 1966), p. 70.

${ }^{3}$ Martin S. Stabb was among the first to bri: attention to three articles, published by Martínez Estrada in Nosotros (Buenos Aires) in 1917-1918, as clear antecedents to the pessimism of Radiografia de la pampa. See "Ezequiel Martínez Estrada: The Formative Writings," Hispania, 49, no. 1 (March, 1966), 54-60. Also worthy of note in this context is a rather similar thesis by Eugenio Pucciarelli in his "La imagen de la Argentina en la obra de Martínez Estrada," Sur (Buenos Aires), 295 (July-August, $1965), 34-48$.

${ }^{4}$ Heraldos de la verdad: Montaigne, Balzac, Nietzsche (Buenos Aires: Editorial Nova, 1957), p. 189.

5 "A mi juicio, es lo mejor (en calidad y en fervor) que yo he producido... Yo estoy absolutamente seguro del pensamiento social y político de Martí; pero no creo que esa 'vera efigie', como las otras, sea reconocida como auténtica. Si nos mostrasen fotografías de Moisés, Cristo y Mahoma, nos horrorizaríamos. Puedo mandar capítulos anticipadamente, para discutir y ganar tiempo. Me horroriza pensar que puedo morir sin ver impresa esa obra." This was part of a letter to Roberto Fernández Retamar, which was reproduced in his "Razón de homenaje," Casa de las Américas (La Habana), 33 (November-December, 1965), 5-14.

6 César Fernández Moreno, "Martínez Estrada frente a la Argentina," Mundo nuevo (Paris), I (July, 1966), p. 46.

7 ¿Qué es esto?, 2nd. ed. (Buenos Aires: Lautaro, 1956), p. 270.

8 The speech was reproduced in "Los escritores frente a una actitud," Atlántida (Buenos Aires), 1123 (September, 1960), 22, 23.

${ }^{9}$ Several Argentine writers were interviewed on the occasion of his exile and most expressed skepticism at the reasons the essayist adduced. See "Los escritores frente a una actitud," above. 
10 Familia de Marti (1962), Martí: el héroe y su acción revolucionaria (1966) and Martí revolucionario (1967). A third volume forming a trilogy with the latter two, and entitled La doctrina, el apóstol, remains as yet unpublished. Other essays of the Cuban period contain frequent references to Martí. See for example En Cuba y al servício de la revolución cubana (1963).

11 Sarmiento (Buenos Aires: Argos, 1956), p. 146.

${ }^{12}$ En Cuba y al servicio de la revolución cubana (La Habana: Ediciones Unión/Ensayo, 1963), p. 99.

13 "Sarmiento y Martí," Cuadernos americanos, 4 (July-August, 1946), 197-214.

14 Análisis funcional de la cultura (La Habana, Ministerio de Educación y Casa de las Américas, 1960), p. 66.

15 Martí revolucionario (La Habana: Casa de las Américas), pp. 102, 107.

16 Ibid., 389.

${ }^{17}$ Martí: el héroe y su acción revolucionaria (México: Siglo XXI Editores, 1966), pp. 11-12. 